\title{
Two Zinc(II) Complexes with Similar Hydrazone Ligands: Syntheses, Crystal Structures and Antibacterial Activities
}

\author{
Ya-Li Sang, ${ }^{\star}$ Xue-Song Lin and Wei-Dong Sun \\ Department of Chemistry and Chemical Engineering, Chifeng University, Chifeng 024000, P. R. China \\ *Corresponding author: E-mail: sangyali0814@126.com
}

Received: 09-20-2019

\begin{abstract}
A pair of new mononuclear zinc(II) complexes with hydrazone ligands 4-methoxybenzoic acid (1-pyridin-2-ylmethylidene)hydrazide $\left(\mathrm{HL}^{\mathrm{a}}\right)$ and benzoic acid (1-pyridin-2-ylethylidene)hydrazide $\left(\mathrm{HL}^{\mathrm{b}}\right)$ were prepared. They are $\left[\mathrm{Zn}\left(\mathrm{L}^{\mathrm{a}}\right)_{2}\right](\mathbf{1})$ and $\left[\mathrm{Zn}\left(\mathrm{L}^{\mathrm{b}}\right)_{2}\right](2)$. The complexes were characterized by physico-chemical methods and single crystal X-ray determination. The tridentate hydrazone ligands coordinate to the $\mathrm{Zn}$ atoms through the pyridine nitrogen, imino nitrogen and enolate oxygen atoms. The $\mathrm{Zn}$ atom in each complex is six coordinated by two hydrazone ligands, to form octahedral coordination. The complexes have effective activities against the bacteria Bacillus subtilis, Staphylococcus aureus, Escherichia coli and Pseudomonas fluorescens.
\end{abstract}

Keywords: Schiff base; Zinc complex; Crystal structure; Antibacterial activity

\section{Introduction}

Schiff bases are readily synthesized by the condensation reaction of aldehydes with primary amines, which have been widely investigated for their antibacterial and antitumor activities. ${ }^{1}$ The metal complexes of Schiff bases have also received much attention due to their contribution to the development of coordination chemistry related to catalysis and enzymatic reactions, magnetism and molecular architectures, ${ }^{2}$ as well as biological activities. ${ }^{3}$ The Schiff bases 4-methoxybenzoic acid (1-pyridin-2-ylmethylidene)hydrazide (HL ${ }^{\text {a }}$; Scheme 1 ) and benzoic acid (1-pyridin-2-ylethylidene)hydrazide ( $\mathrm{HL}^{\mathrm{b}}$; Scheme 1$)$ are interesting tridentate hydrazone-type ligands, which possess potential antibacterial activities. ${ }^{4}$ In this paper, two new mononuclear zinc(II) complexes, $\left[\mathrm{Zn}\left(\mathrm{L}^{\mathrm{a}}\right)_{2}\right](\mathbf{1})$ and $\left[\mathrm{Zn}\left(\mathrm{L}^{\mathrm{b}}\right)_{2}\right](2)$, have been synthesized and structurally characterized. The antibacterial activities against Bacillus subtilis, Staphylococcus aureus, Escherichia coli, and Pseudomonas fluorescens, were evaluated for the complexes.

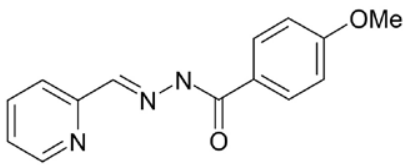

$\mathrm{HL}^{\mathrm{a}}$

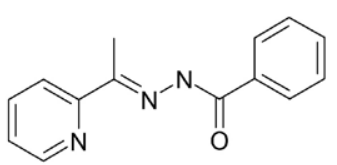

$\mathrm{HL}^{\mathrm{b}}$
Scheme 1. The Schiff bases, $\mathrm{HL}^{\mathrm{a}}$ and $\mathrm{HL}^{\mathrm{b}}$.

\section{Experimental}

\section{1. Materials and Measurements}

Pyridine-2-carbaldehyde, pyridine-2-ethanone, 4-methoxybenzohydrazide, and benzohydrazide with AR grade were obtained from Aldrich and used as received. Elemental analyses $(\mathrm{C}, \mathrm{H}, \mathrm{N})$ were performed using a Perkin-Elmer $240 \mathrm{C}$ analytical instrument. Infrared spectra were recorded on a Nicolet 5DX FT-IR spectrophotometer with $\mathrm{KBr}$ pellets. UV-vis spectra were recorded on a Lambda 900 spectrophotometer.

\section{2. Synthesis of Complex 1}

Pyrdine-2-ethanone $(1.21 \mathrm{~g}, 0.01 \mathrm{~mol})$ and 4-methoxybenzohydrazide $(1.66 \mathrm{~g}, 0.01 \mathrm{~mol})$ were stirred in 30 $\mathrm{mL}$ methanol at room temperature for $20 \mathrm{~min}$. Then, zinc nitrate hexahydrate $(2.97 \mathrm{~g}, 0.01 \mathrm{~mol})$ dissolved in $30 \mathrm{~mL}$ methanol was added dropwise to the solution. The mixture was further stirred for $30 \mathrm{~min}$ and filtered. The filtrate was evaporated slowly in air to give colorless block-like single crystals, which were washed three times with methanol and dried in open air. Yield: 55\%. Found: $\mathrm{C}, 59.72 ; \mathrm{H}, 4.71$; N, 14.13. Anal. Calcd. for $\mathrm{C}_{30} \mathrm{H}_{28} \mathrm{~N}_{6} \mathrm{O}_{4} \mathrm{Zn}$ : C, 59.86; $\mathrm{H}$, 4.69; $\mathrm{N}, 13.96 \%$. IR data $\left(\mathrm{cm}^{-1}, \mathrm{KBr}\right.$ pellet): 1602,1585 , $1562,1511,1495,1455,1407,1361,1317,1300,1289,1247$, $1171,1097,1063,1042,1027,905,840,765,680,635,618$. 
UV-Vis data $\left(\lambda_{\max }(\mathrm{nm}), \varepsilon\left(\mathrm{L} \mathrm{mol}^{-1} \mathrm{~cm}^{-1}\right)\right): 276(1.23 \times$ $\left.10^{3}\right), 325\left(1.38 \times 10^{3}\right), 370\left(1.45 \times 10^{3}\right)$.

\section{3. Synthesis of Complex 2}

Pyrdine-2-ethanone ( $1.21 \mathrm{~g}, 0.01 \mathrm{~mol})$ and benzohydrazide $(1.36 \mathrm{~g}, 0.01 \mathrm{~mol})$ were stirred in $30 \mathrm{~mL}$ methanol at room temperature for $20 \mathrm{~min}$. Then, zinc nitrate hexahydrate $(2.97 \mathrm{~g}, 0.01 \mathrm{~mol})$ dissolved in $30 \mathrm{~mL}$ methanol was added dropwise to the solution. The mixture was further stirred for $30 \mathrm{~min}$ and filtered. The filtrate was evaporated slowly in air to give colorless block-like single crystals, which were washed three times with methanol and dried in open air. Yield: $61 \%$. Found: C, 26.21; H, 4.53; N, 15.40. Anal. Calcd. for $\mathrm{C}_{28} \mathrm{H}_{24} \mathrm{~N}_{6} \mathrm{O}_{2} \mathrm{Zn}$ : C, 62.06; $\mathrm{H}, 4.46$; $\mathrm{N}, 15.51 \%$. IR data $\left(\mathrm{cm}^{-1}, \mathrm{KBr}\right.$ pellet): $1595,1587,1562$, 1498, 1460, 1431, 1357, 1316, 1293, 1169, 1160, 1095, 1060, $1041,903,776,746,708,683,637 . \mathrm{UV}-\mathrm{Vis}$ data $\left(\lambda_{\max }(\mathrm{nm})\right.$, $\left.\varepsilon\left(\mathrm{L} \mathrm{mol}^{-1} \mathrm{~cm}^{-1}\right)\right): 270\left(1.12 \times 10^{3}\right), 310\left(1.29 \times 10^{3}\right), 365$ $\left(1.30 \times 10^{2}\right)$.

\section{4. X-ray Crystallography}

Single crystal structural diffraction was performed on a Bruker Smart 1000 CCD area-detector diffractometer with graphite monochromatized Mo-Ka radiation $(\lambda=$ $0.71073 \AA$ ). Diffraction data for the complexes were collected by $\omega$ scan mode at 298(2) K. Data reduction and cell refinement were performed by the SMART and SAINT programs. ${ }^{5}$ Empirical absorption correction was applied by using SADABS. ${ }^{6}$ Structures of the complexes were solved by direct method and refined with the full-matrix least-squares technique using SHELXL97. ${ }^{7}$ The non-H atoms in the structures were subjected to refined anisotropic refinement. All hydrogen atoms were located in geometrically and treated with the riding mode. Crystallographic data and experimental details for the complexes are summarized in Table 1. Selected bond lengths and angles for the complexes are listed in Table 2.

\section{5. Antibacterial Test}

Antibacterial activities of the Schiff bases and the complexes were tested in vitro against Bacillus subtilis, Staphylococcus aureus, Escherichia coli, and Pseudomonas fluorescens using MH medium (Mueller-Hinton medium: casein hydrolysate $17.5 \mathrm{~g}$, soluble starch $1.5 \mathrm{~g}$, beef extract $1000 \mathrm{~mL}$ ) in triplicate. The minimum inhibitory concentrations (MIC) of the test compounds were determined by a colorimetric method using the dye MTT (3-(4,5-dimethylthiazol-2-yl)-2,5-diphenyltetrazolium bromide). A solution of the compound ( $50 \mu \mathrm{g} \mathrm{mL}^{-1}$ ) in DMSO was prepared and graded quantities of the test compounds were incorporated in specified quantity of sterilized liquid $\mathrm{MH}$ medium. A specified quantity of the medium containing the compound was poured into microtitration plates. Sus-
Table 1. Crystallographic and experimental data for the complexes.

\begin{tabular}{|c|c|c|}
\hline & 1 & 2 \\
\hline Chemical formula & \multicolumn{2}{|l|}{$\mathrm{C}_{30} \mathrm{H}_{28} \mathrm{~N}_{6} \mathrm{O}_{4} \mathrm{Zn}$} \\
\hline \multicolumn{3}{|l|}{$\mathrm{C}_{28} \mathrm{H}_{24} \mathrm{~N}_{6} \mathrm{O}_{2} \mathrm{Zn}$} \\
\hline Formula weight & 601.95 & 541.90 \\
\hline$T(\mathrm{~K})$ & $298(2)$ & $298(2)$ \\
\hline crystal system & orthorhombic & monoclinic \\
\hline space group & $\mathrm{Pbca}$ & $C c$ \\
\hline$a(\AA)$ & $11.9317(7)$ & $10.3526(13)$ \\
\hline$b(\AA)$ & $10.1046(6)$ & $19.287(2)$ \\
\hline$c(\AA)$ & $47.2193(18)$ & $12.3879(19)$ \\
\hline$\beta\left(^{\circ}\right)$ & 90 & $90.536(2)$ \\
\hline$V\left(\AA^{3}\right)$ & $5693.0(5)$ & $2473.3(6)$ \\
\hline$Z$ & 8 & 4 \\
\hline$\rho\left(\mathrm{g} / \mathrm{cm}^{3}\right)$ & 1.405 & 1.455 \\
\hline$\mu(\mathrm{Mo}-\mathrm{Ka})\left(\mathrm{mm}^{-1}\right)$ & 0.909 & 1.032 \\
\hline$F(000)$ & 2496 & 1120 \\
\hline No. of measured reflections & 32450 & 7154 \\
\hline No. of unique reflections & 5299 & 3379 \\
\hline No. of observed reflections & 3633 & 3003 \\
\hline Parameters & 374 & 337 \\
\hline$R_{\text {int }}$ & 0.0500 & 0.0372 \\
\hline Goodness of fit on $F^{2}$ & 1.136 & 1.045 \\
\hline$R_{1}, w R_{2}[I \geq 2 \sigma(I)]^{\mathrm{a}}$ & $0.0490,0.0962$ & $0.0771,0.2050$ \\
\hline$R_{1}, w R_{2}(\text { all data })^{\mathrm{a}}$ & $0.0801,0.1078$ & $0.0847,0.2118$ \\
\hline $\begin{array}{l}\text { Highest peak and } \\
\text { deepest hole }\left(\mathrm{e} \AA^{-3}\right)\end{array}$ & $0.250,-0.321$ & $0.745,-0.490$ \\
\hline
\end{tabular}

${ }^{\mathrm{a}} R_{1}=\mathrm{a}\left|F_{o}\right|-\left|F_{c}\right| / \mathrm{a}\left|F_{o}\right|, w R_{2}=\left[\mathrm{a} w\left(F_{o}^{2}-F_{c}^{2}\right)^{2} / \mathrm{a} w\left(F_{o}^{2}\right)^{2}\right]^{1 / 2}$.

Table 2. Selected bond lengths $(\AA)$ and angles $\left(^{\circ}\right)$ for the complexes.

1

\begin{tabular}{|c|c|c|c|}
\hline \multicolumn{4}{|l|}{ Bond lengths } \\
\hline $\mathrm{Zn} 1-\mathrm{N} 2$ & $2.055(2)$ & $\mathrm{Zn} 1-\mathrm{N} 5$ & $2.058(2)$ \\
\hline $\mathrm{Zn} 1-\mathrm{O} 1$ & $2.099(2)$ & $\mathrm{Zn} 1-\mathrm{O} 3$ & $2.136(2)$ \\
\hline $\mathrm{Zn} 1-\mathrm{N} 4$ & $2.197(3)$ & $\mathrm{Zn} 1-\mathrm{N} 1$ & $2.212(3)$ \\
\hline \multicolumn{4}{|l|}{ Bond angles } \\
\hline $\mathrm{N} 2-\mathrm{Zn} 1-\mathrm{N} 5$ & $174.18(10)$ & $\mathrm{N} 2-\mathrm{Zn} 1-\mathrm{O} 1$ & $75.79(9)$ \\
\hline N5-Zn1-O1 & $109.85(9)$ & $\mathrm{N} 2-\mathrm{Zn} 1-\mathrm{O} 3$ & $103.22(9)$ \\
\hline N5-Zn1-O3 & $74.85(9)$ & $\mathrm{O} 1-\mathrm{Zn} 1-\mathrm{O} 3$ & $99.04(10)$ \\
\hline $\mathrm{N} 2-\mathrm{Zn} 1-\mathrm{N} 4$ & $106.59(10)$ & N5-Zn1-N4 & $75.12(10)$ \\
\hline $\mathrm{O} 1-\mathrm{Zn} 1-\mathrm{N} 4$ & $91.76(10)$ & $\mathrm{O} 3-\mathrm{Zn} 1-\mathrm{N} 4$ & 149.97(9) \\
\hline $\mathrm{N} 2-\mathrm{Zn} 1-\mathrm{N} 1$ & $74.44(10)$ & N5-Zn1-N1 & $100.09(10)$ \\
\hline $\mathrm{O} 1-\mathrm{Zn} 1-\mathrm{N} 1$ & $149.59(9)$ & $\mathrm{O} 3-\mathrm{Zn} 1-\mathrm{N} 1$ & $93.62(10)$ \\
\hline N4-Zn1-N1 & $90.86(11)$ & & \\
\hline \multicolumn{4}{|c|}{2} \\
\hline \multicolumn{4}{|l|}{ Bond lengths } \\
\hline $\mathrm{Zn} 1-\mathrm{N} 2$ & $2.030(9)$ & Zn1-N5 & $2.062(8)$ \\
\hline $\mathrm{Zn} 1-\mathrm{O} 2$ & $2.106(7)$ & $\mathrm{Zn} 1-\mathrm{O} 1$ & $2.137(7)$ \\
\hline $\mathrm{Zn} 1-\mathrm{N} 1$ & $2.184(9)$ & $\mathrm{Zn} 1-\mathrm{N} 4$ & $2.199(8)$ \\
\hline \multicolumn{4}{|l|}{ Bond angles } \\
\hline $\mathrm{N} 2-\mathrm{Zn} 1-\mathrm{N} 5$ & $173.0(3)$ & $\mathrm{N} 2-\mathrm{Zn} 1-\mathrm{O} 2$ & $102.9(3)$ \\
\hline N5-Zn1-O2 & $73.4(3)$ & $\mathrm{N} 2-\mathrm{Zn} 1-\mathrm{O} 1$ & $74.9(3)$ \\
\hline N5-Zn1-O1 & $99.6(3)$ & $\mathrm{O} 2-\mathrm{Zn} 1-\mathrm{O} 1$ & $99.7(3)$ \\
\hline $\mathrm{N} 2-\mathrm{Zn} 1-\mathrm{N} 1$ & $74.9(4)$ & $\mathrm{N} 5-\mathrm{Zn} 1-\mathrm{N} 1$ & $110.9(4)$ \\
\hline $\mathrm{O} 2-\mathrm{Zn} 1-\mathrm{N} 1$ & $92.7(4)$ & $\mathrm{O} 1-\mathrm{Zn} 1-\mathrm{N} 1$ & $149.2(3)$ \\
\hline $\mathrm{N} 2-\mathrm{Zn} 1-\mathrm{N} 4$ & $108.5(3)$ & $\mathrm{N} 5-\mathrm{Zn} 1-\mathrm{N} 4$ & $75.9(4)$ \\
\hline $\mathrm{O} 2-\mathrm{Zn} 1-\mathrm{N} 4$ & $147.9(3)$ & $\mathrm{O} 1-\mathrm{Zn} 1-\mathrm{N} 4$ & $94.6(3)$ \\
\hline $\mathrm{N} 1-\mathrm{Zn} 1-\mathrm{N} 4$ & $89.3(4)$ & & \\
\hline
\end{tabular}


pension of the microorganism was prepared to contain about $10^{5}$ colony forming units cfu $\mathrm{mL}^{-1}$ and applied to microtitration plates with serially diluted compounds in DMSO to be tested and incubated at $37^{\circ} \mathrm{C}$ for $24 \mathrm{~h}$. After the MICs were visually determined on each of the microtitration plates, $50 \mu \mathrm{L}$ of PBS (Phosphate Buffered Saline $0.01 \mathrm{~mol} \mathrm{~L}^{-1}, \mathrm{pH}$ 7.4: $\mathrm{Na}_{2} \mathrm{HPO}_{4} \cdot 12 \mathrm{H}_{2} \mathrm{O} 2.9 \mathrm{~g}, \mathrm{KH}_{2} \mathrm{PO}_{4} 0.2$ g, $\mathrm{NaCl} 8.0$ g, $\mathrm{KCl} 0.2 \mathrm{~g}$, distilled water $1000 \mathrm{~mL}$ ) containing $2 \mathrm{mg}$ of MTT was added to each well. Incubation was continued at room temperature for 4-5 h. The content of each well was removed, and $100 \mu \mathrm{L}$ of isopropyl alcohol containing $5 \% 1.0 \mathrm{~mol} \mathrm{~L}^{-1} \mathrm{HCl}$ was added to extract the dye. After $12 \mathrm{~h}$ of incubation at room temperature, the optical density (OD) was measured with a microplate reader at $550 \mathrm{~nm}$.

\section{Results and Discussion}

The complexes were readily prepared by the reaction of the Schiff bases and zinc nitrate in methanol (Scheme 2). coordinates to the $\mathrm{Zn}$ atom through the pyridine nitrogen, imino nitrogen and enolate oxygen atoms. The coordinate bond lengths in the two complexes are comparable to each other, and also similar to those observed in zinc complexes with similar ligands. ${ }^{8}$ The hydrazone ligands adopt trans configuration with respect to the methylidene unit. The shorter distances of the $\mathrm{C}-\mathrm{N}$ bonds and the longer distances of the $\mathrm{C}-\mathrm{O}$ bonds for the $-\mathrm{C}(\mathrm{O})-\mathrm{NH}-$ units than usual, suggest conjugation effect in the hydrazone molecules. The dihedral angles among the benzene rings and the pyridine rings of the hydrazone ligands are $3.4(5)^{\circ}$ and $20.9(5)^{\circ}$ for $\mathbf{1}$, and $7.4(3)^{\circ}$ and $19.5(3)^{\circ}$ for 2 .

\section{2. IR and Electronic Spectra}

In the spectra of the complexes, the characteristic absorption of the $v(\mathrm{C}=\mathrm{N})$ vibrations are located at $1602 \mathrm{~cm}^{-1}$ for 1 and $1595 \mathrm{~cm}^{-1}$ for $2 .{ }^{9}$ In the UV-Vis spectra of the complexes, the absorptions centered about $270 \mathrm{~nm}$ and $320 \mathrm{~nm}$ are attributed to the $\pi-\pi^{*}$ and $n-\pi^{*}$ transitions of the azomethine chromophores. ${ }^{10}$ The absorptions cen-<smiles>[X]c1ccc(C(=O)N/N=C(\C)c2ccccn2)cc1</smiles>

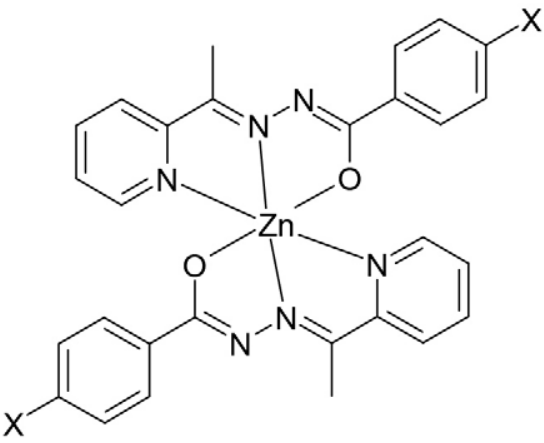

Scheme 2. Synthetic procedure of the complexes. $\mathrm{X}=\mathrm{OCH}_{3}$ for $\mathbf{1}$, and $\mathrm{H}$ for $\mathbf{2}$.

\section{1. Crystal Structure Description}

Molecular structures of complexes $\mathbf{1}$ and $\mathbf{2}$ are shown in Figures 1 and 2, respectively. The $\mathrm{Zn}$ atom in each complex is coordinated by two hydrazone ligands, to form octahedral coordination geometry. The hydrazone ligand

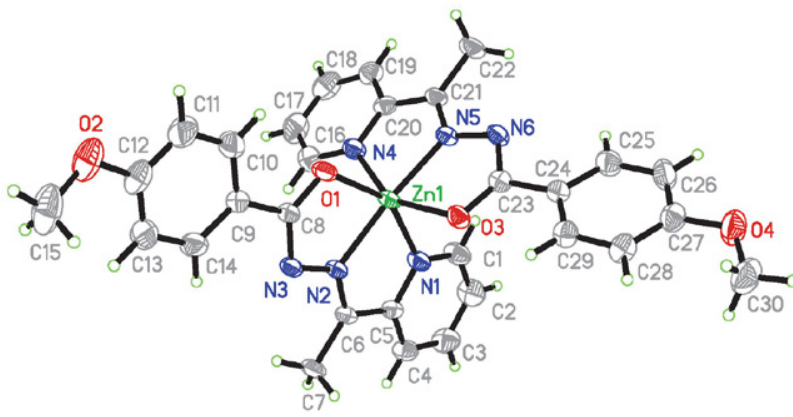

Figure 1. Molecular structures of complex 1 with ellipsoids at 30\% probability.

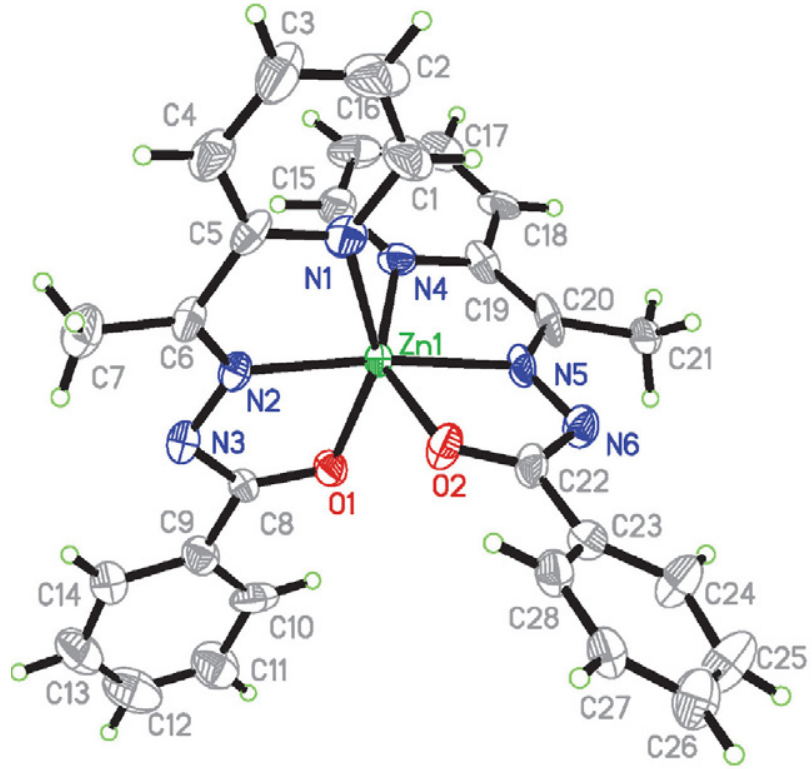

Figure 2. Molecular structures of complex 2 with ellipsoids at 30\% probability. 
tered about $370 \mathrm{~nm}$ may attribute to the ligand to metal charge transfer.

\section{3. Antibacterial Activity}

The Schiff bases and the two complexes were screened in vitro for antibacterial activities against Bacillus www.ccdc.cam.ac.uk, or from Cambridge Crystallographic Data Center, 12, Union Road, Cambridge CB2 1EZ, UK; Fax: +44 1223336 033; e-mail: deposit@ccdc.cam.ac.uk.

\section{Acknowledgments}

We gratefully acknowledge the financial support by

Table 3. Antibacterial results (MIC $\left(\mu \mathrm{g} \mathrm{mL}^{-1}\right)$ ).

\begin{tabular}{lcccc}
\hline Compound & $\begin{array}{c}\text { Bacillus } \\
\text { subtilis }\end{array}$ & $\begin{array}{c}\text { Staphylococcus } \\
\text { aureus }\end{array}$ & $\begin{array}{c}\text { Escherichia } \\
\text { coli }\end{array}$ & $\begin{array}{c}\text { Pseudomonas } \\
\text { fluorescens }\end{array}$ \\
\hline $\mathrm{HL}^{1}$ & 43.1 & 18.5 & 32.6 & $>100$ \\
$\mathrm{HL}^{2}$ & 63.7 & 32.8 & 51.2 & $>100$ \\
$\mathbf{1}$ & 10.2 & 7.8 & 15.4 & 28.5 \\
$\mathbf{2}$ & 17.8 & 19.2 & 27.5 & 45.3 \\
Penicillin & 1.3 & 2.1 & $>100$ & $>100$ \\
\hline
\end{tabular}

subtilis, Staphylococcus aureus, Escherichia coli, and Pseudomonas fluorescens by the MTT method. The MICs of the compounds against the bacteria are presented in Table 3. Penicillin was used as reference drug.

The Schiff base $\mathrm{HL}^{1}$ shows medium antibacterial activities against Staphylococcus aureus, weak activities against Bacillus subtilis and Escherichia coli, and no activity against Pseudomonas fluorescens. The Schiff base $\mathrm{HL}^{2}$ shows weak activities against Bacillus subtilis, Staphylococcus aureus and Escherichia coli, and no activity against Pseudomonas fluorescens. In general, the zinc complexes have stronger activities against all bacteria than the free Schiff bases. The antibacterial activities of complex $\mathbf{1}$ are better than those of complex 2. Complex 1 shows strong activities against Bacillus subtilis and Staphylococcus aureus, medium activity against Escherichia coli, and weak activities against Pseudomonas fluorescens. Complex 2 shows medium activities against Bacillus subtilis, Staphylococcus aureus and Escherichia coli, and weak activity against Pseudomonas fluorescens. As for Escherichia coli and Pseudomonas fluorescens, both complexes have more activities than Penicillin, which deserves further investigation.

\section{Conclusion}

We report the syntheses and crystal structures of two new mononuclear zinc(II) complexes with tridentate hydrazone ligands. The $\mathrm{Zn}$ atoms are in octahedral coordination. Both complexes have effective activities against the bacteria Bacillus subtilis, Staphylococcus aureus, Escherichia coli and Pseudomonas fluorescens.

\section{Supplementary material}

CCDC reference numbers 1578771 (1) and 1578772 (2) contain the supplementary crystallographic data for this paper. These data can be obtained free of charge at the Research Program of Science and Technology at Universities of Inner Mongolia Autonomous Region (NJZY239) and Inner Mongolia Key Laboratory of Photoelectric Functional Materials.

\section{References}

1. (a) Z. H. Chohan, M. ul-Hassan, K. M. Khan, C. T. Supuran. J. Enzyme Inhib. Med. Chem. 2005, 20, 183-188; DOI:10.1080/14756360500043257

(b) J. Zhang, F. Pan, H. Cheng, W. Du. Russ. J. Coord. Chem. 2010, 36, 514-519; DOI:10.1134/S1070328410070067

(c) A. Iqbal, H. L. Siddiqui, C. M. Ashraf, M. H. Bukhari, C. M. Akram. Chem. Pharm. Bull. 2007, 55, 1070-1072.

DOI: $10.1248 / \mathrm{cpb} .55 .1070$

2. (a) A. Lalehzari, J. Desper, C. J. Levy. Inorg. Chem. 2008, 47, 1120-1126; DOI:10.1021/ic702015u

(b) L. Xu, Y. Li, M. Duan, Y. Li, M. Han, J. Wu, Y. Wang, K. Dong, Z. You. Polyhedron 2019, 165, 138-142;

DOI:10.1016/j.poly.2019.03.016

(c) Y. Li, L. Xu, M. Duan, B. Zhang, Y. Wang, Y. Guan, J. Wu, C. Jing, Z. You. Polyhedron 2019, 166, 146-152;

DOI:10.1016/j.poly.2019.03.051

(d) M. Duan, Y. Li, L. Xu, H. Yang, F. Luo, Y. Guan, B. Zhang, C. Jing, Z. You. Inorg. Chem. Commun. 2019, 100, 27-31. DOI:10.1016/j.inoche.2018.12.009

3. (a) G. B. Bagihalli, P. G. Avaji, S. A. Patil, P. S. Badami. Eur. J. Med. Chem. 2008, 43, 2639-2649;

DOI:10.1016/j.ejmech.2008.02.013

(b) Z. H. Chohan, M. Arif, A. Rashid. J. Enzyme Inhib. Med. Chem. 2008,23, 785-796; DOI:10.1080/14756360701450145

(c) Z. H. Chohan, M. Arif, Z. Shafiq, M. Yaqub, C. T. Supuran. J. Enzyme Inhib. Med. Chem. 2006, 21, 95-103; DOI:10.1080/14756360500456806

(d) Y. Li, L. Xu, M. Duan, J. Wu, Y. Wang, K. Dong, M. Han, Z. You. Inorg. Chem. Commun. 2019, 105, 212-216;

DOI:10.1016/j.inoche.2019.05.011 
(e) Z. You, H. Yu, B. Zheng, C. Zhang, C. Lv, K. Li, L. Pan. Inorg. Chim. Acta 2018, 469, 44-50;

DOI:10.1016/j.ica.2017.09.011

(f) H.-L. Zhu, X.-Z. Zhang, Y. Gu, A. Liu, F. Liu, Z. You, Y. Li. Acta Chim. Slov. 2016, 63, 721-725.

4. (a) M. Zhang, D.-M. Xian, H.-H. Li, J.-C. Zhang, Z.-L. You. Aust. J. Chem. 2012, 65, 343-350; DOI:10.1071/CH11424

(b) P. G. Avaji, C. H. V. Kumar, S. A. Patil, K. N. Shivananda, C. Nagaraju. Eur. J. Med. Chem. 2009, 44, 3552-3559;

DOI:10.1016/j.ejmech.2009.03.032

(c) M. J. Hearn, M. H. Cynamon, M. F. Chen, R. Coppins, J. Davis, H. J.-O. Kang, A. Noble, B. Tu-Sekine, M. S. Terrot, D. Trombino, M. Thai, E. R. Webster, R. Wilson. Eur. J. Med. Chem. 2009, 44, 4169-4178.

DOI:10.1016/j.ejmech.2009.05.009

5. Bruker. SMART and SAINT. Bruker AXS, Madison, WI, 2002.

6. G. M. Sheldrick. SADABS. Program for Empirical Absorption
Correction of Area Detector; University of Göttingen, Germany, 1996.

7. G. M. Sheldrick. SHELXTL V5.1 Software Reference Manual; Bruker AXS, Inc., Madison, WI, 1997.

8. (a) H.-H. Li, Z.-L. You, C.-L. Zhang, M. Yang, L.-N. Gao, L. Wang. Inorg. Chem. Commun. 2013, 29, 118-122;

DOI:10.1016/j.inoche.2012.12.023

(b) Z.-L. You, M. Zhang, D.-M. Xian. Dalton Trans. 2012, 41, 2515-2524; DOI:10.1039/c1dt11566a

(c) S. Basak, S. Sen, S. Banerjee, S. Mitra, G. Rosair, M. T. G. Rodriguez. Polyhedron 2007, 26, 5104-5112.

DOI:10.1016/j.poly.2007.07.025

9. X.-M. Hu, L.-W. Xue, G.-Q. Zhao, Y.-J. Han. Synth. React. Inorg. Met.-Org. Nano-Met. Chem. 2012, 42, 557-562.

DOI:10.1080/15533174.2011.613884

10. L.-W. Xue, X. Wang, G.-Q. Zhao. Synth. React. Inorg. Met.Org. Nano-Met. Chem. 2012, 42, 1334-1338.

DOI:10.1080/15533174.2012.680139

\section{Povzetek}

Sintetizirali smo dva nova enojedrna cinkova(II) kompleksa s hidrazonskima ligandoma 4-metoksibenzojsko kislino (1-piridin-2-ilmetiliden)hidrazidom $\left(\mathrm{HL}^{\mathrm{a}}\right)$ in benzojsko kislino (1-piridin-2-iletiliden)hidrazidom $\left(\mathrm{HL}^{\mathrm{b}}\right),\left[\mathrm{Zn}\left(\mathrm{L}^{\mathrm{a}}\right)_{2}\right](\mathbf{1})$ in $\left[\mathrm{Zn}\left(\mathrm{L}^{\mathrm{b}}\right)_{2}\right](2)$. Kompleksa sta bila okarakterizirana s fiziko-kemijskimi metodami in monokristalno rentgensko difrakcijo. Tridentatna hidrazonska liganda se koordinirata na $\mathrm{Zn}$ atom preko piridinskega dušikovega atoma, iminskega dušikovega atoma in enolatnega kisikovega atoma. Zn atom v obeh kompleksih ima koordinacijsko število šest in je koordiniran z dvema hidrazonskima ligandoma v oktaedrični geometriji. Kompleksa sta učinkovita proti bakterijam Bacillus subtilis, Staphylococcus aureus, Escherichia coli in Pseudomonas fluorescens.

Except when otherwise noted, articles in this journal are published under the terms and conditions of the Creative Commons Attribution 4.0 International License 